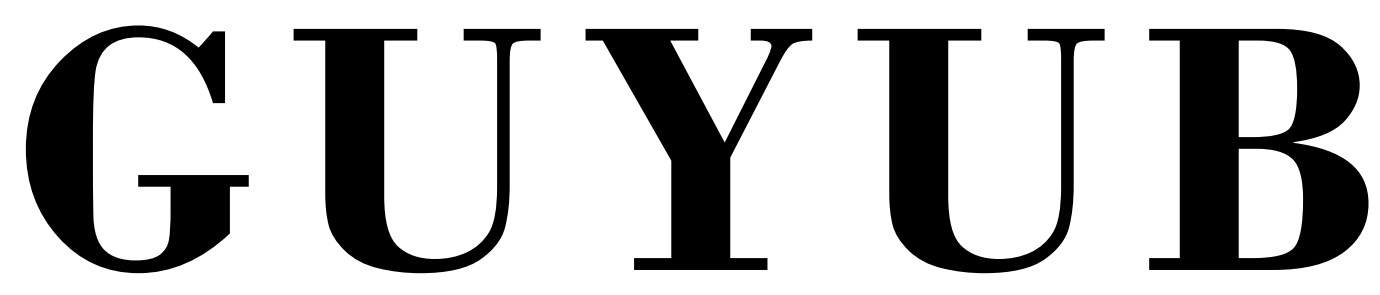

Journal of Community Engagement

Vol. 2, No. 2, Agustus 2021

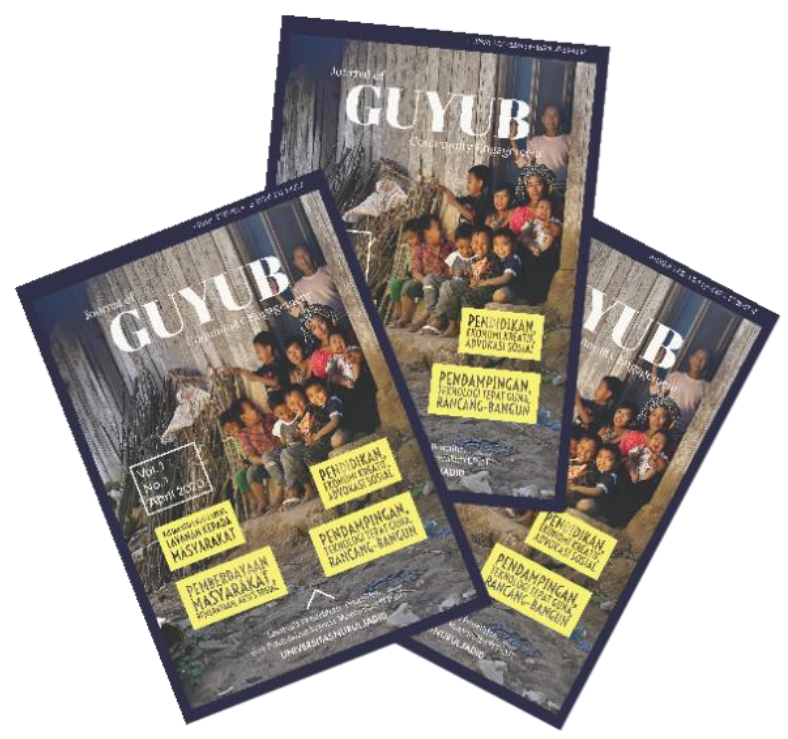

PKM Pendampingan Santri Nurul Jadid melalui Gerakan Literasi Cerdas dalam Membentuk Komunitas Pelajar Berkarakter Islam di Pondok Pesantren Nurul Jadid

Faizatul Widat, Afita Khoirun Nisa', Wardatul Habibah, Wahibatul Mas'ula, Nikmatul Hosniah, Jamilatul Masnunah, Hamidah

PKM Penyuluhan Pembuatan dan Penyemprotan Disinfektan (PEPEDES) sebagai Upaya Pencegahan Covid-19 di Desa Kalikajar Kulon Probolinggo

Fahrudin, Ayu Midyah Putri, Abdul Hamid Isnaini, Abdul Latif Isnaini, Duwi Handika Okta Rotama, Rosi Nurjannah, Suharno

PKM Pendampingan Penyusunan Kurikulum Sekolah Ramah Anak pada Taman Kanak Kanak (TK) Az-Zainiyah II Paiton Probolinggo

Abu Hasan Agus R, Durratul Mashunah, Hostin, Hilyah Mashunah, Siti Rahayu, Atik Hikmatuz Zakiyah 


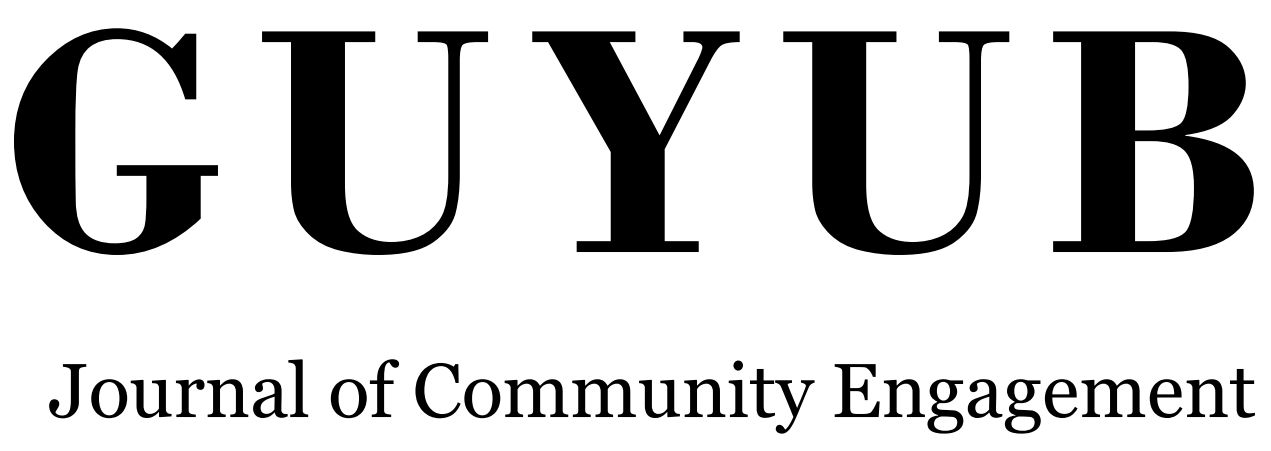




\section{G U Y U B}

\section{Journal of Community Engagement}

Vol. 2, No. 2, 2021

\section{Editor in Chief}

Achmad Fawaid, (SCOPUS ID: 57214837323)

\section{Managing Editors}

Hasan Baharun, (ID SCOPUS : 57200983602)

Sugiono Sugiono, (SCOPUS ID : 57199578160)

Ismail Marzuki, (SCOPUS ID: 57201500245

Subhan Rachman, (SCOPUS ID: 57192937912)

Nurul Huda, (SINTA ID: 6119615)

Syamsuri, (SINTA ID: 6116825)

Ridhatullah Assya'bani, (SINTA ID: 6200862)

\section{Peer Reviewers}

Miftahul Huda, (SINTA ID: 6171566), University of Antwerp, Belgium Achmad Naufal Irsyadi (SINTA ID: 6704870), Universitas Nurul Jadid, Indonesia Sukamto Sukamto, (SINTA ID: 5979034), Universitas Widya Gama Malang, Indonesia Deny Utomo, (SINTA ID: 6016108), Universitas Yudharta Pasuruan, Indonesia Fariz Alnizar, (SCOPUS ID: 6659824), UNUSIA Jakarta, Indonesia Fuad Rahman, (SCOPUS ID: 57201474778), UIN Sulthan Thaha Saifuddin Jambi, Indonesia Saifuddin Zuhri Qudsy, (SCOPUS ID: 57213595165), UIN Sunan Kalijaga Yogyakarta, Indonesia Akhmad Anwar Dani, (SINTA ID: 14305), IAIN Surakarta, Indonesia Maufur Maufur, (SINTA ID: 5989329), IAIN Kediri, Indonesia Siti Mahmudah Noorhayati, (SINTA ID: 6726997), IAIN La Roiba Bogor, Indonesia Busro Busro, (SCOPUS ID: 57205022652), UIN Sunan Gunung Djati Bandung, Indonesia Akmal Mundiri, (SCOPUS ID: 57205059378), UNUJA Probolinggo, Indonesia

\section{Section Editor}

Ahmad Zubaidi, Universitas Nurul Jadid, Probolinggo, Indonesia 
GUYUB: Journal of Community Engagement is a multidisciplinary journal which aims to disseminate the conceptual thoughts and research results in the area of community service. This journal focuses on the main problems of the community engagement areas, such as (1) training, marketing, appropriate technology, design; (2) student community services; (3) community empowerment, social access; (4) education for sustainable development, etc.

GUYUB: Journal of Community Engagement is published three times a year (April, August, December) by Lembaga Penerbitan, Penelitian, dan Pengabdian kepada Masyarakat (LP3M) Universitas Nurul Jadid, Paiton, Probolinggo, Jawa Timur, Indonesia.

Editorial Office:

GUYUB: Journal of Community Engagement

Lembaga Penerbitan, Penelitian, dan Pengabdian kepada Masyarakat (LP3M) Universitas Nurul Jadid, Paiton, Probolinggo, Jawa Timur, Indonesia 67291.

Phone: 088830 77077, Hp: 082318007953

Email: jurnal.guyub@gmail.com

Website: https://ejournal.unuja.ac.id/index.php/guyub/index 


\section{Tables of Content}

178-191

PKM Pendampingan Santri Nurul Jadid melalui Gerakan Literasi Cerdas dalam Membentuk Komunitas Pelajar Berkarakter Islam di Pondok Pesantren Nurul Jadid

Faizatul Widat, Afita Khoirun Nisa', Wardatul Habibah, Wahibatul Mas'ula, Nikmatul Hosniah, Jamilatul Masnunah, Hamidah

192-201

PKM Pelatihan Deep-Listening untuk Meningkatkan Kemampuan Berbahasa Inggris Santri Nurul Jadid Durratul Hikmah, Taufiqur Rahman, Irfan Wahyudi, Nur Hayati, Ahmad Zainullah, Kuni Zakiya Maskuroh

$202-210$

PKM Pendampingan Speaking Skill dengan Metode TROPIG di Wilayah Al Hasyimiyah Pondok Pesantren Nurul Jadid

Syaiful Islam, Nur Azizah, Rifdatul Qomariyah, Anis Fitria, Nurul Hamidah, Masrufah Masrufah

\section{1-224}

PKM Penyuluhan Pembuatan dan Penyemprotan Disinfektan (PEPEDES) sebagai Upaya Pencegahan Covid-19 di Desa Kalikajar Kulon Probolinggo

Fahrudin, Ayu Midyah Putri, Abdul Hamid Isnaini, Abdul Latif Isnaini, Duwi Handika Okta Rotama, Rosi Nurjannah, Suharno

225-232

PKM Pelatihan Pengisian Pengajuan Izin Operasional Taman Pendidikan Al-Quran secara Online Moh Jasri, Muhammad Romdloni, Mohammad Akmalor Riski, Nurul Hidayatullah, Muhammad Hasan Andika, Yogi Angga Praditya, Syukron Khafi, Shancen Ammabiel

\section{3-249}

PKM Pelatihan Pemanfaatan E-Learning Berbasis Teknologi Berbasis Platform Google Classroom bagi Guru Madrasah Ibtidaiyah Nurul Mun'im (MINM) Paiton Probolinggo

Feriska Listrianti, Nur Ika Sari, Siti Khomariya, Huswatun Hasanah, Millatun Hanifah, Deviyatul Hasanah

250-264

PKM Pelatihan Tutor Lembaga Kebahasaan Az-Zainiyah melalui Game Islami untuk Meningkatkan Keterampilan Berbicara Bahasa Inggris

Bradhiansyah Tri Suryanto, Nur Hasanah, Nuril Diar Anas, Sri Waliyul Hasanah, Syaiful Syaiful, Lia Umami

\section{5-275}

PKM Deteksi Dini Kelainan Tumbuh Kembang dengan Skrining Denver II dan Health Education di Taman Pendidikan Anak Shaleh Nurul Jadid Paiton Probolinggo

Zainal Munir, Zainul Hasan, Siti Nur Kholishoh, Melinia Akhirul Fitri 
PKM Habituasi Nilai-Nilai Keagamaan melalui Kegiatan Rohani DITABERHAMAN dalam Menciptakan Kesalehan Sosial di Pondok Mahasiswi (POMASI) Nurul Jadid Paiton Probolinggo

Zakiyah BZ, Ana Muthmainnah, Aminatuz Zuhriyah, Hamidah Hamidah, Miftahul Jannah, Wardatus Sholihah, Elok Nafiqoh

293-302

PKM Diversifikasi Ragam Produk Olahan Berbahan Dasar Ikan Teri sebagai Upaya Peningkatan Ekonomi Masyarakat Paiton Probolinggo

Saifuddin, Andre Dimas Fernando Putra, Moch Sofyan, Fadhlur Rohman, Mohammad Hasan Ainul Yaqin, Nailis Saadah Ali

303-312

PKM Pendampingan Penyusunan Kurikulum Sekolah Ramah Anak pada Taman Kanak Kanak (TK) AzZainiyah II Paiton Probolinggo

Abu Hasan Agus R, Durratul Mashunah, Hostin Hostin, Hilyah Mashunah, Siti Rahayu, Atik Hikmatuz Zakiyah

\section{3-325}

PKM Pelaksanaan Kegiatan Ekstrakurikuler Keagamaan dalam Membangun dan Mengembangkan Bakat dan Minat Santri pada Bidang Keagamaan di Madrasah Tsanawiyah (MTs) Nurul Jadid Probolinggo

Abdullah, Habibaturrohmah Habibaturrohmah, Halimatus Sakdiyah, Aisyah Amini, Putri Yunita Sari, Lilis Sulistiawati, Fitriyatun

326-341

PKM Sosialisasi Aplikasi Edmodo sebagai Alternatif Media Pembelajaran Daring di Madrasah Ibtidaiyah (MI) Az-Zainiyah II Paiton Probolinggo

Niken Septantiningtyas, Suhairiyah Suhairiyah, Fadilatul Hasanah, Umatuz Sholihah

$342-350$

PKM Pendampingan Pelatihan Penulisan Karya Tulis IImiah dalam Meningkatkan Kompetensi Guru di Madrasah Tsanawiyah (MTs) Nurul Jadid Paiton Probolinggo

Musolli Ready, Moh. Amir Kholili, Moh. Abd Mu'iz, Jefri Jefri, Moh. Agus, Moh. Ridwan Kamil

$351-360$

PKM Literasi Penguatan 3-M (Memakai Masker, Mencuci Tangan, dan Menjaga Jarak) Melalui Metode Storytelling di Pondok Pesantren Nurul Jadid Probolinggo

Mohammad Sofyan Adi, Dina Nur Faizah, Kamelia Yulia Novita, Robiatul Adawiyah, Ulfatul Nimatillah, Nuriah Waizul Romdani

361-368

PKM Pendampingan Pembelajaran Materi Bangun Datar dengan Billingual LED Running Text di Madrasah Ibtidaiyah (MI) Az-Zainiyah II Paiton Probolinggo

Nur Hamid, Muhammad Faiz Nailun Ni'am, Cahyu Guswita, Saiful Islam, Silviana Qomariyah, Siti Fatimah, Siti Khoifah

369-383

PKM Pendampingan Literasi Business Plan untuk Meningkatkan Pengetahuan dan Keterampilan Berwirausaha Santri Pesantren Nurul Jadid Mohammad Syaiful Suib, Yoviana Fitri, Lailatus Sa'adah, Nuril Fitriani, Widad Ulfatul Mawaddah Hadi, Siti Aisyah, Isna Shifah 
384-403

PKM Penanaman Karakter Berbasis Keagamaan bagi Warga Binaan Rumah Tahanan Kelas II. B Kraksaan Probolinggo Jawa Timur

Ahmad Fawaid, Muhammad Zaimul Millah, Achmad Naufal Baidawi, Siti Arofah, Nur Khofifah, Elmiyatus Soliha, Syukron Jazila, Rif'ah Hasanah, M Zainuddin

404-416

PKM Pendampingan Menghafal Al-Quran dengan Metode An-Nur pada Siswa Kelas X IPA Tahfidz Madrasah Aliyah Nurul Jadid Paiton Probolinggo

Abdurrahman, Indriani Putri Ayu Lestari, Lailia Mutmainnah, Hakimatus Sailah, Ika Fitri Anwar, Sofiya Mauliza, Nadya Afkarina

417-423

PKM Peningkatan Pendapatan pada Bidang Keputrian Wilayah Az-Zainiyah Pondok Pesantren Nurul Jadid melalui Strategi Pemasaran Berbasis Web

Anis Yusrotun Nadhiroh, Dina Wahyuni Suciati, Dzurrotun Nafila, Eva Nurmaliya, Nabila Maulidir Roziqina Fara 


\title{
Pendampingan Santri Nurul Jadid melalui Gerakan Literasi Cerdas dalam Membentuk Komunitas Pelajar Berkarakter Islam di Pondok Pesantren Nurul Jadid
}

Faizatul Widat ${ }^{1}$, Afita Khoirun Nisa' ${ }^{2}$, Wardatul Habibah' ${ }^{3}$, Wahibatul Mas'ula $^{4}$, Nikmatul Hosniah ${ }^{5}$, Jamilatul Masnunah ${ }^{6}$, Hamidah $^{7}$

Universitas Nurul Jadid 1,2,3,4,5,6,7

\{ faizatulwidat59@gmail.com¹, fitapinky@gmail.com², fitajiwa@gmail.com, bubunyaafita@gmail.com, nikmatulhusniyah60@gmail.com, lisaledista489@gmail.com, mahrusfirdani300@gmail.com \}

Submission: 2021-04-25 Received: 2021-08-30 Published: 2021-08-31

\begin{abstract}
Keywords:
Mentoring,

Abstract: The purpose of this community service was to foster the Literacy interest in reading which has begun to erode with the development iteracy of information technology that is increasingly colonizing the nation, movement, including those who are still in elementary school. The activity of Islamic this intelligent literacy movement was an effort to form a student

Character community at Islamic character. The method used is based on mentoring the learning community at MI Nurul Mun'im. Internal applicative data that has become a success in the field, firstly adding media books according to interest in reading that can foster curiosity and reading material containing moral values through stories of the prophets and caliphs, strengthening faith and Islamic values through Islamic Figh and the pillars of faith and the cultivation of noble morality through Islamic children's moral books, with the existence of this book it can attract reading interest in the learning community of MI Nurul Mun'im so that it can form a student community with Islamic character. The second approach is through the guardians of students as controlling children's reading when outside the school area. The reading method was also applied to those who were still not fluent in reading.
\end{abstract}


Katakunci: Pendampingan; Gerakan Literasi; Karakter Islami
Tujuan pendampingan ini untuk menumbuhkan minat membaca yang sudah mulai terkikis dengan berkembangnya teknologi informasi yang semakin menjajah bangsa, tak terkecuali mereka yang masih berada di Sekolah Dasar. Kegiatan gerakan literasi cerdas ini merupakan upaya membentuk komunitas pelajar berkarakter islam. Metode yang digunakan berbasis pendampingan terhadap komunitas belajar di MI Nurul Mun'im. Upaya yang dilakukan, antara lain, sebagai berikut. Pertama, pendekatan literasi dengan menambahkan media buku sesuai daya ketertarikan minat membaca yang dapat menumbuhkan rasa keingintahuan serta materi baca berisi nilai-nilai budi pekerti melaui kisah nabi dan para khalifah, penguatan nilai-nilai keimanan dan keislaman melaui Fiqih Islam dan rukun iman serta penanaman Akhlaq Mulia melalui buku Akhlaq anak islam, dengan adanya buku tersebut dapat menarik minat baca terhadap Komunitas belajar Ml Nurul Mun'im sehingga dapat membentuk komunitas pelajar berkarakter Islam. Kedua, pendekatan melaui wali murid sebagai controling membaca anak ketika berada di luar kawasan sekolah. Metode membaca juga diterapkan bagi mereka yang masih kurang lancar dalam membaca.

\section{Pendahuluan}

Saat ini bangsa Indonesia sedang mengalami krisis Moral dan karakter. Pembangunan karakter merupakan tujuan utama dari sistem pendidikan. Penanaman nilai-nilai karakter sangat diperlukan saat usia dini baik pendidikan sekolah maupun pendidikan luar sekolah. Bagaimanapun pendidikan karakter mutlak diperlukan bukan hanya disekolah saja, tapi di lingkungan sosial (Omeri, 2015:465).

Pada dasarnya, tujuan utama penanaman karakter adalah untuk membangun generasi yang bermoral, berakhlaq baik, toleransi dan tanggung jawab. Dalam islam, karakter memiliki kesamaan dengan kata Akhlaq, adab dan syakhsiyah yaitu sama- sama menunjukkan kepribadian dan budi pekerti. Namun penanaman akhlaq itu tumbuh dari kemauan keras seseorang.

Pendidikan karakter merupakan kurikulum yang dikembangkan untuk mengajar anak-anak tentang sifat-sifat penting yang diperlukan untuk mengembangkan karakter yang baik. Hal tersebut merupakan upaya untuk mengembangkan karakter mulia dan menumbuhkan perilaku yang layak bagi individu dan masyarakat secara keseluruhan. (Direktorat jenderal pendidikan dasar dan menengah kementrian dan kebudayaan: 2016). 
Karakter islami lebih merujuk pada penanaman akhlaq baik dalam islam yang meliputi akhlaq baik manusia dengan manusia, manusia dengan penciptanya dan manusia pada seluruh ciptanyaannya. Implementasi penanaman suatu nilai karakter islami dapat dilakukan dengan membaca dan menulis atau biasa disebut dengan kegiatan literasi (Handayani, 2020).

literasi saat ini sangat penting mengingat dengan budaya literasi yang tertanam dalam diri peserta didik dapat mempengaruhi tingkat keberhasilannya, baik di sekolah maupun dalam kehidupan bermasyarakat. Banyak dari ilmuwan menganggap bahwa literasi sebagai hak warga negara yang wajib difasilitasi oleh setiap negara. Secara sederhana, literasi merupakan kemampuan memahami, mengelola, dan menggunakan informasi dalam konteks (Hartati, 2017).

Dalam sebuah definisi lain yang senada dengan pendapat tersebut juga menjelakan literasi sebagai kemampuan membaca dan memahami teks, grafik, tabel, dan diagram dalam konteks (Pamungkas, 2017). Aan Nurhasah menuturkan, kemampuan literasi juga dapat berupa kemampuan menyaring dan mengeloha informasi sehingga dapat bermanfaat bagi diri manusia (Nurhasaanah, 2016). Oleh karena itu dapat disimpulkan bahwa kemampuan literasi ini berupa beberapa komponen yaitu kemampuan mengakses, memahami, dan memanfaatkan informasi secara cerdas.

Selain literasi dalam pendidikan membangun karakteristik islami merupakan suatu upaya terencana dan sistematis demi untuk menjadikan peserta didik mengenal, peduli dan menginternalisasikan nilai-nilai islam sehingga peserta didik tersebut berperilaku sebagai insan kamil. Dalam pendidikan karakter islami memiliki makna yang lebih tinggi dari pada pendidikan moral karena, pendididikan karakter islami tidak hanya mengajarkan mana yang benar dan mana yang salah akan tetapi pendidikan menanamkan kebiasaan berbuat baik sehingga peserta didik mampu merasakan dan mau melakukan hal yang baik.

Kegiatan literasi diharapkan dapat menumbuhkan sikap simpati dan empati siswa sehingga siswa dapat menerima suatu nilai yang pada akhirnya mengarahkan untuk berperilaku positif (Rahayu, 2017).

Kegiatan Literasi yang di lakukan oleh Tim Pendampingan di MI Nurul Mun'im Karanganyar Paiton mengalami beberapa hambatan. Penerapan 
kegiatan Literasi pada Siswa sekolah dasar tidak sama dengan penerapan literasi pada sekolah tingkat menengah.

Ada beberapa faktor yang menyebabkan sedikitnya minat kegiatan literasi tersebu. Pertama, rata-rata siswa kelas 1 dan kelas 2 masih belum lancar membaca bahkan masih ada juga yang belum bisa membaca. Kedua, media yang disediakan oleh pihak sekolah kurang menarik perhatian siswa. Ketiga, penggunaan metode yang kurang variatif dan menarik bagi siswa, karena masih cenderung menggunakan metode yang bersifat konvensional sehingga, siswa hanya sekedar membaca tanpa mengambil hal-hal positif dari apa yang dibaca. Keempat, kurangnya perhatian dalam kegiatan literasi.

Media menjadi pendukung utama untuk mendorong minat baca anak. Media merupakan segala sesuatu yang dapat menyalurkan pesan, dapat merangsang pikiran, perasaan dan kemauan peserta didik (Fajriyah, 2015; Zubaidillah dan Hasan, 2019).

Di lingkungan MI Nurul Mun'im. Pendidikan sekolah dasar memerlukan media yang terlihat menarik dan juga tidak membosankan agar dapat menarik minat budaya literasi mereka. Salah satu media yang dapat digunakan adalah buku-buku bergambar, warna-warna yang bervariasi, dan berbentuk cerita, sehingga terlihat menarik bagi siswa ketika membaca.

Tujuan tim pendampingan ini menggunakan Literasi untuk menciptakan karakter islami adalah untuk menumbukan rasa suka mereka terhadap membaca. Selain itu agar mereka mampu memahami dan mengambil nilai positif dari apa yang mereka baca, sehingga karakter islami dapat tumbuh dan mampu diterapkan dalam kehidupan sehari-hari.

\section{Metode}

Langkah pemberdayaan yang Tim pendamping lakukan di MI Nurul Mun'im Karanganyar Paiton Probolinggo berbasis pendampingan. Pelaksanan gerakan lliterasi cerdas di sekolah MI Nurul Mun'im kelas bawah yakni 1 dan 2 serta pada kelas atas yakni 3 dan 4 dengan menggunakan metode penelitian deskriptif kualitatif.

Penelitian deskriptif mengumpulkan data berdasarkan faktor-faktor yang menjadi pendukung objek penelitian, kemudian menganalisisnya untuk mencari peranannya Arikunto (2010:151). Penelitian kualitatif menurut 
Cresswel adalah penelitian yang menghasilkan penemuan-penemuan yang tidak dapat dicapai dengan menggunakan prosedur statistik atau cara-cara lain dari kuantifikasi (Rahmat, 2009:2).

Dalam penelitian ini peneliti mengkaji implementasi gerakan literasi cerdas sebagai pembentuk pendidikan berkarakter. Objek penelitian ini adalah di MI Nurul Mun'im Karanganayar Paiton. Analisis data dalam penelitian ini dilakukan dengan teknik Observasi, Pendampingan, Wawancara dan dokumentasi.

Teknik Observasi dilakukan sebagai peninjauan awal guna melihat dan mencermati keadaan situasi lapangan yang akan di berikan pendampingan. Teknik wawancara digunakan untuk mengumpulkan data pelaksanaan program literasi pada tahapan pembiasaan, tahapan pengembangan kegiatan Literasi cerdas di MI Nurul Mun'im Karanganyar Paiton. Data dokumentasi digunakan untuk mengumpulkan data SOP (Standar Operasional Prosedur).

Pada penelitian kali ini, teknik dokumentasi yang digunakan bersumber dari data siswa di MI Nurul Mun'im Karanganyar Paiton. Selain itu, dokumentasi juga diambil dari dokumen hasil kegiatan literasi siswa di MI Nurul Mun'im, sedangkan dokumentasi berupa foto diambil pada saat pelaksanaan kegiatan literasi cerdas yang berlangsung diperpustakaan dan di rumah siswa mengigat Covid-19 masih melanda. Kegiatan literasi cerdas ini dilaksanakan dengan cara siswa kelas 1 dan 2 membaca buku metode AIUEO dan bagi kelas 5 dan 6 membaca buku karakter islami selama 30 menit setiap harinya. Dalam pengumpulan data, digunakan instrumen berupa pedoman wawancara dan alat perekam. 


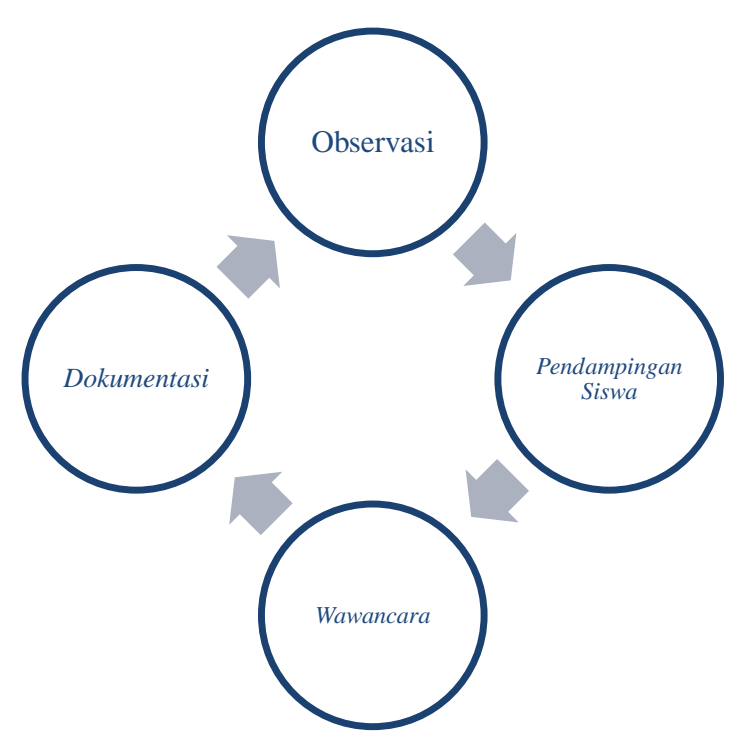

Gambar 1: tahapan-tahapan yang dilakukan oleh tim pendampingan

\section{Hasil dan Pembahasan}

\section{Pelaksanaan Penerapan Literasi Cerdas Untuk Membentuk Komunitas Pelajar Berkarakter Islami Di MI Nurul Mun'im Karanganyar, Paiton, Probolinggo}

Minat baca yang rendah dikalangan anak-anak Indonesia sebaiknya tidak dianggap remeh. Sebab, buku adalah sarana pendidikan yang tepat untuk tumbuh kembang. Selain bermanfaat untuk menambah wawasan, dengan membaca dapat mengembangkan imajinasi anak.

Karakter merupakan sikap atau perilaku yang ada pada dirimanusia. Karakter bagian dari tabiat, sifat-sifat kejiwaan, akhlak, watak, atau budi pekerti yang membedakan seseorang dengan yang lainnya. Menurut Samrin (2016:123) mengatakan bahwa nilai-nilai perilaku manusia yang universal meliputi seluruh aktivitas manusia, baik dalam rangka berhubungan dengan tuhan, dengan dirinya, dengan sesama manusia, maupun dengan lingkungannya yang terwujud dalam pikiran sikap, perasaan, perkataan, dan perbuatan. Jadi karakter ialah perilaku yang penting dimiliki oleh manusia dalam kehidupan sehari-hari. 
Pembentukan karakter dapat dilakukan dalam kegiatan literasi cerdas. Menurut budi (2017), penanaman nilai-nilai karakter siswa melalui gerakan literasi sekolah dasar merupakan proses humanisasi pendidikan dan upaya menumbuh kembangkan budi pekerti, karakter siswa di sekolah, sehingga menjadikan pembelajaran sepanjang hayat yang berkarakter baik.

Oleh karena itu, gerakan literasi sekolah salah satu tindakan dalam mengatasi permasalahan karakter. Pada intinya, pembentukan karakter pada diri kita itu dimulai dari kita sejak kecil atau sejak di masa sekolah dasar bisa dari budi pekerti, pembelajaran, pembentukan karakter yang baik dan sosial yang baik, dan ini akan dilakukan sepanjang hidup.

\section{Tahapan Pertama proses pendampingan gerakan literasi cerdas untuk membentuk komunitas pelajar berkarakter islami di MI Nurul Mun'im}

Pendampingan gerakan literasi cerdas di MI Nurul Mun'im oleh tim PKM Yang dilaksanakan sebagai bentuk upaya meningkatkan budaya minat baca siswa di MI Nurul Mun'im Karanganyar Paiton Probolinggo.

Kegiatan ini digawangi oleh Lembaga Penerbitan, Penelitian, dan Pengabdian Masyarakat (LP3M) Universitas Nurul Jadid Paiton Probolinggo, mengeluarkan izin kepada Mahasiswa untuk melaksanakan kegiatan Pendampingan. Selanjutnya, tim Pendampingan menentukan tempat yang akan diberikan pendampingan, yakni MI Nurul Mun'im Karanganyar, Paiton, Probolinggo. Tim Pendampingan Berkoordinasi dengan bapak $\mathrm{H}$. Abdurrahman Wafie selaku kepala madrasah MI Nurul Mun'im yang kemudian di serahkan kepada Bapak Umar Falas, M.Pd selaku WAKA MI Nurul Mun'im. Observasi tempat pelaksanaan dilakukan setelah mendapatkan izin dari Bapak Umar Falas, M. Pd selaku WAKA MI Nurul Mun'im. Beliau sangat mengapresiasi kegiatan ini. Menurutnya, kegiatan ini sangat penting dilakukan untuk perubahan kualitas membaca anak didik MI Nurul Mun'im.

Selanjutnya sesuai dengan hasil koordinasi dan observasi dengan WAKA MI Nurul Mun'im Yakni Bapak Umar Falas, M.Pd, maka Tim PKM melakukan kerja sama dengan pengurus perpustakaan MI Nurul Mun'im yaitu Ibu Lailatul Qodariyah, S.E. untuk mempersiapkan metode dan bahan yang digunakan untuk literasi. Metode pendampingan oleh Tim PKM tidak hanya 
dilaksanakan secara tatap muka disekolah melainkan juga dengan Kuling (Kunjungan Keliling) dirumah masing-masing melalui kegiatan berkelompok sambil lalu mengikuti protokol kesehatan. Tim PKM turut serta menambah koleksi buku perpustakaan dengan beberapa macam buku cerita bergambar yang bergenre islam.

Kemendikbud (2016:10-22) menjelaskan bahwa memilih materi bacaan dari berbagai macam sumber dimaksudkan agar siswa memiliki wawasan yang luas dan menjadikan membaca sebagai kegiatan yang tidak membosankan.

Respon siswa terhadap koleksi terbaru perpustakaan MI Nurul Mun'im sangat baik. Antusias para siswa terhadap literasi semakin meningkat. Namun pendampingan gerakan literasi cerdas ini tidak berlangsung lama dikarenakan terbatasnya waktu dan situasi yang tidak kondusif sebab covid19, maka kegiatan ini hanya terlaksana selama 15 hari.

Dampak Perubahan pada aspek proses peberdayaan gerakan literasi cerdas untuk membentuk komunitas pelajar berkarakter islam di MI Nurul Mun'im Karanganyar, Paiton, Probolinggo

Sesuai dengan metode AIUEO untuk kelas 1 dan 2 serta disediakan media buku yang menarik bagi kelas 3 dan 4 yang digunakan dalam proses pemberdayaan ini, maka proses tahapan-tahapan pemberdayaan di $\mathrm{Ml}$ Nurul Mun'im Karanganyar Kecamatan Paiton Kabupaten Probolinggo dilakukan sesuai dengan tahapan yang ada di metode AIUEO yang digunakan di atas akan dijelaskan sebagai berikut:

Pertama, Define. Pendamping atau pelaku pemberdayaan menentukan "pilihan topic" dalam melakukan pendampingan di masyarakat. Di dalam tahapan ini terdapat beberapa langkah yang dilakukan yaitu: a) menentukan topic. Topic ini ditentukan pada tanggal 10 Februari 2021 oleh kelompok KKN dan dospem. Topic yang ditentukan yaitu: pendampingan tim PKM dan peserta didik dalam pengembangan gerakan literasi cerdas untuk menumbuhkan karakter islami; b) Mengupayakan Peserta didik yang masih kurang lancar membaca melalui kegiatan literasi cerdas; b) melakukan kesepakatan bekerjasama dengan pihak sekolah. 
Kedua, Habituation. Dalam tahapan ini, tim PKM melakukan proses pembiasaan. Dimana lebih ditekankan kepada upaya menjadikan membaca sebagai kebiasaan. Karena dengan kegiatan gerakan literasi cerdas mempunyai tujuan untuk membentuk karakter islami peserta didik.

Ketiga, Dream. Tahapan ini merupakan mimpi atau keinginan atau tujuan yang diharapkan komunitas pendamping dalam membentuk karakter islami. Adapun hasil rumusan tujuan atau impian yang diinginkan ialah membentuk karakter islami pada peserta didik melalui gerakan literasi cerdas.

Keempat, Design. Pada tahap ini, tim PKM memulai untuk merumuskan strategi, proses dan system yang mendukung terwujudnya penyelesaian masalah komunitas dampingan dan perubahan yang diharapkan dari komunitas dampingan. Adapun hasil desain program yang akan dilakukan untuk mewujudkan keinginan atau tujuan yang telah ditetapkan tersebut yaitu:

1) Merumuskan strategi program pendampingan. Strategi program pendampingan berbentuk pelatihan dan pendampingan lancar membaca dengan menggunakan beberapa media seperti, buku cerita dan video yang bernuansa islami.

2) Menyusun proses program dampingan. Proses program dampingan ini berkaitan dengan beberapa hal, yaitu: a) waktu pelaksanaannya. Waktu pelaksanaan tersebut dilaksanakan pada tanggal 10 Februari 2021 jam 10:00-11:30. b) pelaksanaan pendampingan oleh Tim PKM tidak hanya dilaksanakan secara tatap muka disekolahmelainkan juga dengan kuling (kunjungan keliling) dirumah masing-masingmelalui kegiatan berkelompok sambil lalu mengikuti protokol kesehatan ; c) pematerinya yang melakukan pendampingan ialah tim PKM dan ustadz-ustadzah MI Nurul Mun'im ; d) SDM yang terlibat dalam pendampingan tersebut adalah asatidz dan peserta didik MI Nurul Mun'im Karanganyar Paiton

Kelima, Learning. Dalam tahap pembelajaran ini terdapat beberapa prinsip yang perlu dilaksanakan pada tahap pembelajaran, yaitu buku yang menjadi bahan bacaan berupa buku kegemaran, cerita islami atau teks multimedia, dan juga dapat membaca buku yang berkaitan dengan mata pelajaran tertentu. Dalam learning terdapat tahapan yang akan dilakukan, yaitu: 
1) Tahap pelaksanaan. Sebagaimana waktu kegiatan pendampingan yang telah dilakukan di tahap design, maka ditemukan bahwa pendampingan melalui gerakan literasi cerdas untuk membentuk komunitas pelajar berkarakter islami di MI Nurul Mun'im pada hari Rabu tanggal 10 Februari 2021, jam 10:00- 11:30 Pelaksanaan tersebut berjalan dengan lancar dan sukses mulai dari ta'aruf, proses kegiatan lancar membaca, dan penutup.

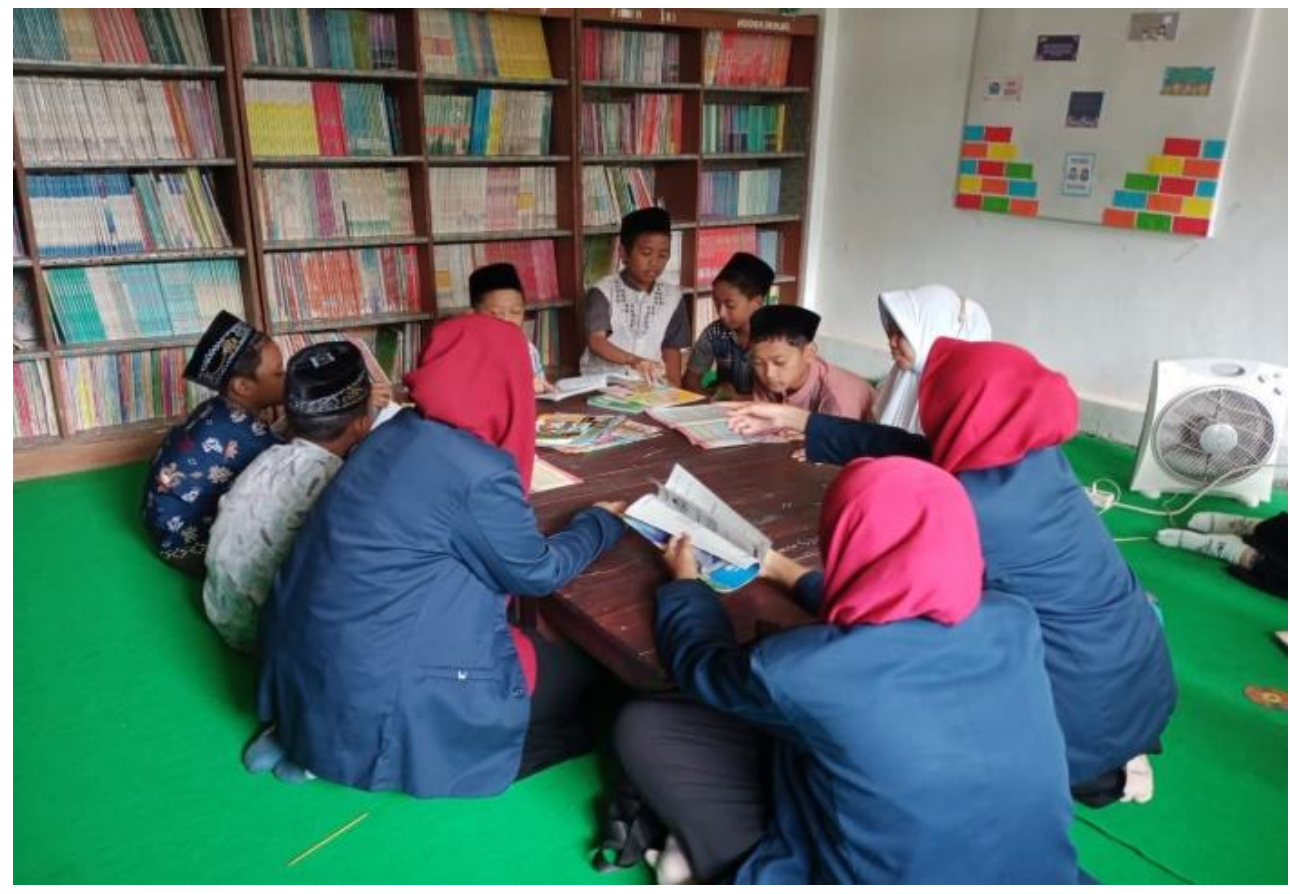

Gambar 2 : Peserta didik sedang melaksanakan kegiatan literasi cerdas bersama tim pendampingan di ruang perpustakaan

Perubahan pada aspek hasil pemberdayaan kegiatan literasi cerdas menggunakan metode AIUEO pada kelas 1 dan 2 di MI Nurul Mun'im desa Karangnyar Kecamatan Paiton Kabupaten Probolinggo

Proses pemberdayaan yang telah dilakukan baik dari tahap Define, Habituation, Dream, Design dan Learning. Maka ada perubahan yang telah dilakukan yaitu:

1) Dengan metode AIUEO ini, peserta didik termotivasi untuk membaca dengan melihat sosok guru yang memeragakan isi bacaan. Pengalaman membaca yang menyenangkan bagi siswa tersebut terbangun komunikasi antara guru dan peserta didik. Selain membaca nyaring, tim 
PKM berusaha membuat peserta didik berkonsentrasi membaca. Buku yang dibaca adalah buku yang sesuai dengan minat peserta didik yang tanpa mengesampingkan konten bacaan pada buku tersebut.

2) Media pembelajaran semakin banyak dan variatif di MI Nurul Mun'im Karanganyar Paiton. Sebelum tim PKM ke lembaga tersebut, sumber belajar sudah ada seperti yang biasa ada di lembaga-lembaga lainnya. Setelah proses pemberdayaan dilakukan di lembaga tersebut, maka sumber belajar bertambah dengan sumber belajar buku karakter islami guna memudahkan dalam pembentukan karakter islami.

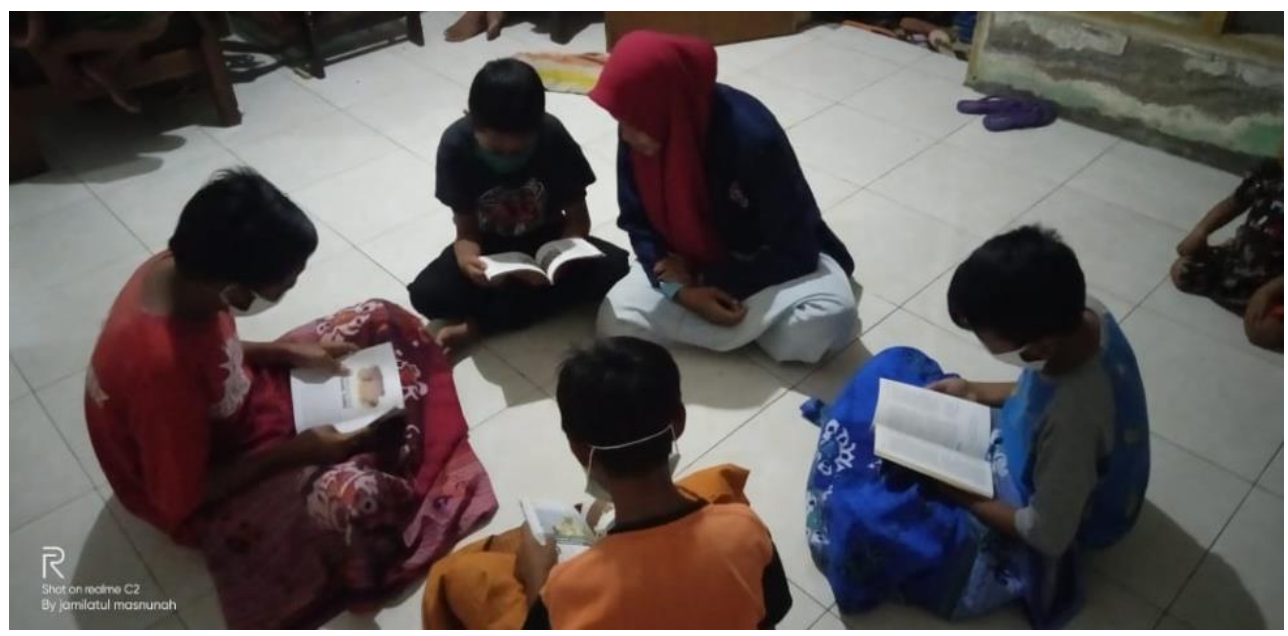

Gambar 3 : Pelaksanaan Kegiatan Literasi Cerdas yang dilakukan dirumah siswa secara berkelompok dengan mengikuti protokoll kesehatan

\section{Perubahan pada aspek hasil kegiatan Literasi Cerdas Untuk membentuk karakter islami di MI Nurul Mun'im Karanganyar Paiton Probolinggo}

Dalam kegiatan literasi yang dilakukan oleh pihak pendampingan memerlukan fasilitas atau media sebagai penunjang kegiatan tersebut, adapun media yang pihak pendampingan sediakan yaitu berupa buku bacaan sesuai dengan minat baca siswa di MI Nurul Mun'im, buku tersebut beruba materi pembelajaran dan kisah tauladan serta tidak lupa pihak pengabdian juga menyediakan buku metode membaca untuk anak kelas bawah yang masih belum bisa membaca. 
Dengan adanya buku tersebut diharapkan siswa dapat menarik kesimpulan postif yang dibacanya.

Kegiatan literasi cerdas Guna membentuk Generasi berkarakter islami di MI Nurul Mun'im yang telah dilakukan sesuai dengan penerapan metode pendampingan serta penyediaan media buku yang telah disediakan, maka ada perubahan yang tampak, yaitu sebagai berikut:

1. Peserta didik lebih sering mengunjungi perpustakaan. Adanya media yang disediakan, Contohnya buku-buku baca yang disertai gambar dan varian warna. Tampilan buku yang demikian akan meningkatkan semangat anak dalam belajar dan juga melatih kemampuan kognitif nya lebih baik. Bentuk-bentuk warna yang berbeda-beda meningkatkan ketertarikan anak untuk belajar dan juga meningkatkan gemar belajar.

2. Bagi peserta didik yang mempunyai rasa malas untuk membaca, PKM menggunakan aplikasi game edukasi dalam membantu proses belajar anak. Pada zaman yang serba digital saat ini, hal ini sudah bukan rahasia lagi. Game pada smartphone atau computer bisa melatih perkembangan anak menjadi semakin kreatif dan solutif. Game edukasi yang berkembang kini sudah banyak. Orang tua perlu menyeleksi game mana yang tepat. Aplikasi game edukasi juga beragam, mulai dari permainan kata, permainan berhitung, menggambar, mewarnai, dan lain sebagainya.

3. Sikap jujur, tidak pemalas serta rajin membaca mulai tertanam dalam diri peserta didik dengan adanya kegiatan literasi tersebut.

\section{Kesimpulan}

Berdasarkan hasil pendampingan kepada peserta didik MI Nurul Mun'im Karanganyar dengan menggunakan metode AIUEO dan media yang menarik dapat disimpulkan bahwa pendampingan dalam menanamkan karakter islami berhasil dalam proses dampingan. Metode AIUEO telah mempengaruhi kepada peserta didik guna memudahkan dalam mempraktekkan kosakata lancar membaca dalam keseharian mereka dan media yang di sediakan oleh tim pendampingan menarik minat baca siswa yang semula malas akhirnya mulai terbiasa membaca. Metode tersebut menunjukkan bahwa pemberdayaan yang dilakukan tim PKM kepada siswa 
MI Nurul Mun'im ternyata berdampak pada kemudahan dalam mengembangkan minat baca. Pada intinya metode AIUEO serta media buku yang menarik memudahkan dan memperlancar dalam program kegiatan literasi cerdas untuk menciptakan pelajar berkarakter islam.

\section{Pengakuan}

Alhamdulillah, puji syukur kita atas terlaksananya kegiatan pendampingan dalam membentuk komunitas pelajar berkarakter islam melalui kegiatan literasi cerdas. Tim pengabdian mengucapkan banyak terima kasih kepada MI Nurul Mun'im Karanganyar, Paiton, Probolinggo yang telah memfasilitasi atas terlaksananya pelatihan dan pendampingan ini. Tim pendampingan juga mengucapkan terima kasih kepada Ibu Faizatul Widad, M.Pd selaku dosen pembimbing yang telah memberi bimbingan kepada rim pengabdian selama proses pendampingan berlangsung.

\section{Referensi}

Aisyi, Ghufron, Hidayat, Rahayu. 2020. Gerakan Literasi Sekolah Pelaksanaan, Hambatan, dan Solusi (Studi Kasus di SD Ghufron Faqih Surabaya). Genta Mulia. Volume XI No 2. hal, 95

Arikunto S. 2010. Prosedur Penelitian Suatu Pendekatan Praktik. Jakarta: PT Rineka Cipta

Direktorat Jenderal Pendidikan Dasar dan Menengah Kementerian Pendidikan dan Kebudayaan. 2016. Panduan Gerakan Literasi Sekolah di Sekolah Menengah Pertama. Jakarta: Direktorat Jenderal Pendidikan Dasar dan Menengah Kementerian Pendidikan dan Kebudayaan.

Fajriah, Z. (2015). Peningkatan Penguasaan Kosakata Bahasa Arab (Mufradat) Melalui Penggunaan Media Kartu Kata Bergambar. Jurnal Pendidikan Usia Dini, 9(1)

Hartati, 2017, Pendidikan Karakter Islam Perspektif Pendidikan IsIm, Jurnal Pendidikan, 1 (08) 
Hendrawan, Budi. 2017. Kajian Aplikatif Penanaman nilai-nilai karakter siswa melalui Gerakan Literasi Sekolah di Sekolah Dasar Berdasarkan Perspektif Pedagodik Kritis. Jurnal Pendidikan dan Pembelajaran di Sekolah Dasar, 1(2)

Nurhasanah, 2016, Pendidikan Karakter Islam Perspektif Pendidikan Islam, Jurnal Pendidikan 2 (08)

Omeri, Nopan, 2015, Pentingnya Pendidikan Karakter Dalam Dunia Pendidikan, Jurnal Manajer Pendidikan,. 9 (3)

Pamungkas, 2017, Pendidikan Karakter Islam Perspektif Pendidikan Islam, Jurnal Pendidikan, 1 (08)

Rahayu, Agustina Ratih. dkk. 2017. Gerakan Literasi Sekolah Sebagai Upaya Penumbuhan Karakter Siswa Sekolah Dasar. Jurnal Transformasi Pendidikan Abad 21, 15(7)

Ramandanu Febriana. 2019. Gerakan Literasi Sekolah (GLS) melalui Pemanfaatan Sudut Baca Kelas sebagai Sarana Alternatif Penumbuhan Minat Baca Siswa. Jurnal mimbar ilmu. Vol 2 No. 24. Hal, 13

Samrin, 2016. Pendidikan Karakter (Sebuah Pendekatan Nilai). Jurnal AlTa'dib, 9(1)

Yaqin, Yunus, Risqi. 2020. Pendampingan Komunitas Lembaga Pendidikan Bahasa Arab dalam Pembelajaran Al- Mufradat Melalui Media Flash Card di Lembaga Pendidikan Bahasa Arab (LPBA) Al-Qodiri Jember. Guyub. Vol 1 No. 3. hal, 17

Zubaidillah, M. H., \& Hasan, H. (2019). Pengaruh Media Kartu Bergambar (Flash Card) Terhadap Penguasaan Kosakata Bahasa Arab. Al Mi'yar: Jurnal Ilmiah Pembelajaran Bahasa Arab dan Kebahasaaraban, 2(1)

Handayani, T. U. (2020). Penguatan Budaya Literasi Sebagai Upaya Pembentukan Karakter. Jurnal Literasi, 4(1), 67-69. 


\section{GUYUB}

\section{Journal of Community Engagement}

P-ISSN: 2723-1232

E-ISSN: 2723-1224

GUYUB: Journal of Community Engagement is is a multidisciplinary journal which aims to disseminate the conceptual thoughts and research results in the area of community service. This journal focuses on the main problems of the community engagement areas, such as (1) training, marketing, appropriate technology, design; (2) student community services; (3) community empowerment, social access; (4) education for sustainable development, etc.

GUYUB: Journal of Community Engagement is published three times a year (April, August, December) by Lembaga Penerbitan, Penelitian, dan Pengabdian kepada Masyarakat (LP3M) Universitas Nurul Jadid, Paiton, Probolinggo, Jawa Timur, Indonesia.

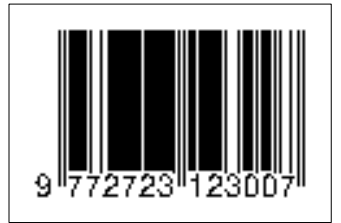

Editorial Office:

GUYUB: Journal of Community Engagement

Lembaga Penerbitan, Penelitian, dan Pengabdian kepada Masyarakat

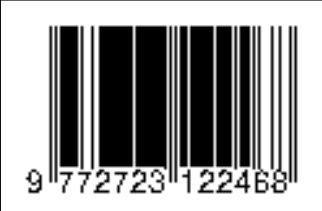

(LP3M) Universitas Nurul Jadid, Probolinggo, Jawa Timur, Indonesia 67291.

Phone: 088830 77077, Hp: 082318007953

Email: jurnal.guyub@gmail.com

Website: https://ejournal.unuja.ac.id/index.php/guyub/index 